\title{
Project Finance Model for Small Contractors in USA
}

L. Jawahar Nesan (Department of Civil and Construction Engineering, College of Engineering \& Applied Sciences, Western Michigan University, Michigan, USA)

\section{ABSTRACT}

Construction projects do not require a large capital outlay but a large working capital to start up the project. Unfortunately, for small contractors there are very limited options available from the banks or other lending institutions to cover this large working capital requirement in the absence of sufficient collateral. The "Project Finance" method presented in this paper is recommended as the most effective method for small contractors in the United States. The problems of small and start up contractors in funding their projects have been little addressed in the literature. The current financing practices were observed through both the literature review and interviews with contractors and bankers in the western Michigan area and subsequently a system has been proposed which could help a small start-up company seeking higher growth. The growth rates that can be achieved using the project finance system in contrast to the traditional "line of credit" arrangements as illustrated in this paper show that the project finance model is beneficial.

Key Words: construction financing, contractor financing, project financing, construction cash flow, financing small firms

\section{INTRODUCTION}

One of the most pressing problems in construction projects is the working capital and liquidity required to support day-to-day activities. More construction companies go out of business due to lack of liquidity to support their day-to-day activities rather than lack of technical capability to perform the job (Singh and Lokanathan, 1992).
Over 10,000 construction firms failed in the United States in 1997, up from 8000 failures in 1990. The business failure rate of construction firms is about 30 percent higher than the national average of all industries (Schaufelberger, 1991). Besides various other reasons inefficient construction financing becomes the most critical cause for this failure. This paper reviews the existing financial practices in the construction industry and proposes a new project financing model for financing small and medium scale contractors.

\section{CURRENT PROBLEMS IN CONSTRUCTION FINANCING}

The financing problem for small contractors is illustrated in the Figure 1. The finance problem for a new construction firm starts after the firm has learnt to handle the cash flow for its projects, skillfully. Thereafter a need for working capital is perceived in order to bid and execute multiple projects simultaneously. During the period of adolescence, which is a period of up to 4 years (as discussed below) from start up, fund may be required to aid in juggling between a number of cash flows, due to the lack of credit support from suppliers. After the period of adolescence when the firm is reasonably stabilized and aiming for higher growth, yet again there is a requirement for greater amount of funds. Unplanned regional growth and consequent excessive bidding and work orders result in severely straining the company's financial position. This perpetual need for fund to fuel growth calls for an appropriate project specific financing mechanism. The problems associated with project financing are briefly discussed as below. 


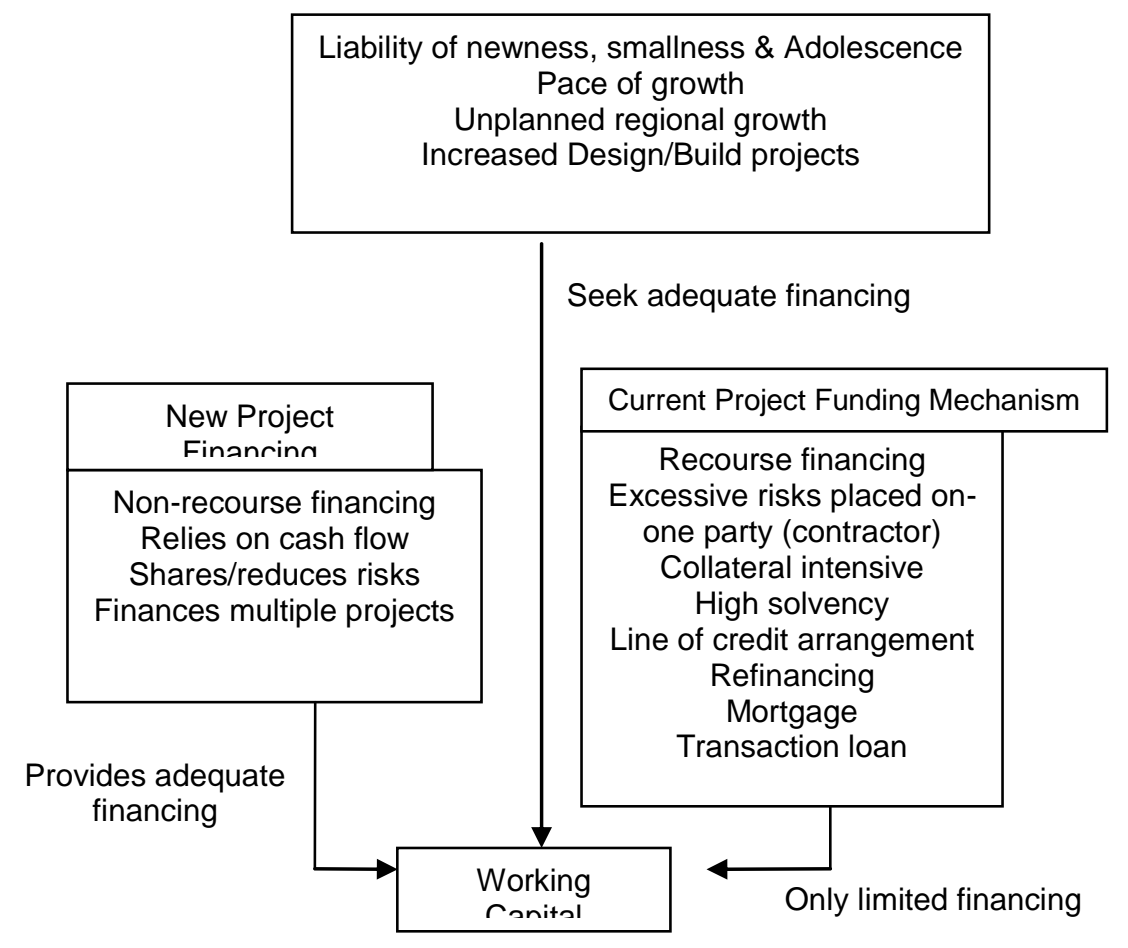

Figure 1: Project financing problems for small contractors

\section{THE LIQUIDITY PROBLEM}

Some of the most common internal problems attributed to liquidity in construction firms are poor cash flow prediction and multiple contracts undertaken simultaneously. These internal factors coupled with an ill-structured progress measurement system financially weaken small construction firms. Several researchers have highlighted the cash management problem. Navon (1996), Abudayyeh \& Rasdorf (1993), Carr (1993), and Cook (1991) all have dealt with the problem of cash flow or expense flow from different perspectives. While some have attempted to predict the cash flow by integrating the cost and schedule, others have generated mathematical models for forecasting the cash flow for a project.

\section{THE WORKING CAPITAL PROBLEM}

It is very difficult for a small company, with limited resources, to work simultaneously on multiple contracts due to the requirement of a large working capital. Thus the contractors are restricted by the availability of liquidity or solvency. The 1992 census of the US Government, "Census of construction industries" showed that though there were a huge number of construction companies, only the large corporations had considerable financial strength to take up the bulk of the job, while smaller companies, among other reasons, were handicapped on the account of the need for working capital.

\section{PACE OF GROWTH}

Construction industry forms an excellent cause for the application of the concept of sustainable growth as it is more dependent on cash flow and working capital as compared to other industries. If the concept of sustainable growth is applied to a typical hypothetical construction firm using national averages as shown below, then the growth rate can be arrived as follows.

$$
\text { Sustainable growth rate }=\left(\frac{P(1-d)(1+L)}{T-P(1-d)(1+L)}\right)
$$

(Westerfield and Jaffe, 1996)

[Where, $T=$ Average Sales to Assets ratio $=241 \%$ (BizStats, 2002), $\mathrm{P}=$ Average Profit margin $=6.3 \%$ (BizStats, 2002), $d$ = Average Dividend pay out ratio $=45 \%$ (UBS Warburg, 2002)' and $L=$ Average Debt equity ratio $=2.05$ (BizStats, 2002) 


$$
\begin{aligned}
\text { Sustainable growth rate } & =\frac{0.063(1-0.45)(1+2.05)}{2.41-0.063(1-0.45)(1+2.05)} \\
& =4.58 \%
\end{aligned}
$$

This is lower than the average industry actual growth rate of $7 \%$ as can be seen from census material referenced above. It thus becomes obvious that contractors often seek fund to finance the additional growth.

\section{UNPLANNED GROWTH AND UNPREDICTABLE FUNDS REQUIREMENT}

The problem of unplanned growth has been highlighted in the (year 2000) survey of CFMA (Construction Finance Managers Association). According to the survey, $65 \%$ of the contractors anticipated growth in their business volumes but only $25 \%$ believed that their growth would be the result of planned regional growth (CFMA, 2002). This implies that it is very difficult to precisely predict the working capital. Normally, with a longer lead-time it is easier to arrange finance while it is very difficult to arrange finance at a short notice. To efficiently address this problem, lenders or bankers will have to adapt a new finance system to quickly ascertain the contractor's financial capability, investigate the credit worthiness of the owners and lend accordingly to the need of such projects.

\section{LIABILITIES OF A NEW COMPANY}

Further, the need for a higher and sustained growth is emphasized by Kale and Arditi (1998). By analyzing the age distribution of failed construction companies and computing age specific failure probabilities over a period of ten years, from 1985 to 1994 , they identified the period of adolescence, being 3 to 4 years, lies in the region of increased risk. According to them, failure risk in the US construction industry increases initially with increasing age, reaches a peak point and decreases there after, as companies grow older over a period of 10 years.

\section{THE NEW PROJECT FINANCING} ARRANGEMENT

Besides other performance related problems, the critical factors including liability of newness, smallness and adolescence, pace of growth, and unplanned regional growth could be held responsible for the increased rate of business failures among the small construction firms. To efficiently handle these factors, a suitable construction financing system needs to be developed for small contracting businesses so that the liabilities and risks brought about by them can be efficiently addressed and the deteriorating business conditions of the construction firms and increased rate of failure can be eliminated.

The 'line of credit' mechanism predominates construction financing. Other forms of credit supports are limited to refinancing, mortgage, and transaction loans (Cushman and Bigda, 1985). The commonality among all these credit support mechanisms is that all of them are collateral intensive and the banks unfailingly scrutinize the capital adequacy of the company that seeks fund. The situation as it exists now is almost an impasse, wherein high solvency is imperative for obtaining finance to fund growth, which in turn is responsible for higher earnings and solvency. The margins in the construction industry are also not sufficient to cause any significant growth rate. Thus it is the fact that the growth is ultimately related to the amount of collateral that a company can produce.

The concept of 'project finance' that has been traditionally ignored for small contracting businesses can be considered in this situation as it promises opportunities for financing based on the project cash flow along with reduced risks. Project finance is a non recourse type, asset based financing of an economically separable capital investment project. The lenders in this case look primarily into the cash flow from the project as their source of fund to service the loans and provide a return on the equity being invested in the project (Finnerty, 1996). The distinguishing feature of project financing from conventional financing is that unlike conventional financing the lenders do not have recourse to the entire portfolio of assets of the project sponsor, instead rely only upon the cash flow of that specific project. It becomes possible for the lenders to take on high risk in Project Financing that incorporates appropriate risk assessment and risk transfer. However variants of this form do exist in models wherein the lenders have a limited recourse to the asset portfolio of the project sponsor. In any project finance model the terms of the debt and equity 
securities are tailored to the cash flow characteristics of the project.

In developing a new approach that will manage the credit risk of lending to contractors through contractual and other bond obligations, the asset based limited recourse project specific financing can be used. The nature of the activity of a contractor is such that the contractor has to produce some significant constructed output by investing in the project in order to raise a bill and be paid by the owner thus putting the cash flow in motion. Traditionally, the contractor is seldom the project owner and it is only the owner who qualifies for construction finance. Permanent finance is again out of question, as the contractor is rarely involved in the constructed facility during postconstruction period and does not have an ownership stake in the constructed facility. Commercial mortgage backed securities are instruments for reselling an existing permanent loan or mortgage. This entirely discounts the contractor. Mortgage again is ownership based and since the contractor has no ownership stake in the constructed facility, he/she cannot mortgage the constructed facility. However the contractor can mortgage any other property in which he/she has ownership stake and use the fund advanced on the mortgaged property to start up a construction project. Refinancing is a method of harnessing the appreciated value of a property without selling the property. The contractor can thus refinance some of his/her own properties in which he/she may have an ownership stake, in order to finance one or more projects. Both methods while useful for a contractor to raise funds are indeed collateral intensive. Transaction loans which are primarily very short-term loans advanced to contractors based on the amount of immediate receivables do not require any collateral, besides, such loans are normally very transaction specific. On the other hand project financing which is an outcome of extensive risk analysis and transfer has contractual agreements put in place such that the revenue generated by the asset is paid back to the lenders. It then follows that non-recourse financing can be secured if sufficient risk analysis and transfer or insurance is carried out on a project by project basis.

Assuming that such extensive risk analysis and transfer can be done, the non-recourse funding to a contractor will imply assets taking shape in the form of lien rights that the bank will come in possession of funding the contractor. The cash flow of the construction project will serve the loan and similar loans can be successively drawn under the same arrangement for a particular project to fund the cash requirement of the contractor throughout the project. However various other risks such as diversion of cash flow, cost overrun, non-payment of suppliers, and the credit risk of the bank all necessitate a formal contractual structure. Such a contractual arrangement is proposed and illustrated in Figure 2.

The central theme of this new model is that the banker is recognized by both the contractor and owner as the "Third party beneficiary" for all of the contractor's invoices. It emphasizes the creation of a 'Trust Fund' account jointly operated by both the banker and the contractor. As the model is heavily dependent upon the non-recourse or limited recourse financing by the bank, the banker should have the right/privilege to operate or control the income generated by its investment. According to the model, the owner pays the bills periodically as per the contract to the trust fund joint account. The balance amount after payment of bank dues will be accrued into the contractor's own account. This new approach can be implemented still within the original conditions of AIA (American Institute of Architects) contracts in conjunction with the opportunities available in other avenues such as UCC (Uniform Commercial Code). In order that this model has a scope for implementation, the contractual and risk issues including cost overrun, bankruptcy, sub contractors' or laborers' payment related to this new approach need to be resolved.

Assigning a 'Third Party Beneficiary' right to the banker who is not a party to the original contract is a major challenge to be addressed in this approach. Assignment is not a situation where the original parties create rights in a third party as a part of the original contract. Rather, some or all of the rights of the original parties are transferred to someone who is not a party. These days assignment of rights is an essential part of commercial financing. As per the USA Uniform Commercial Code ( UCC Article 9), rights to the payment of money for goods sold or services rendered can be transferred or assigned to third parties either as a security for debt or as an outright sale. In a way, the debtor's right to pay his/her creditor is destroyed. The creditor can assign the right to receive the debtor's payment to anyone and the debtor can be required to pay that person. Under the UCC (9-318), the debtor can 
demand proof that the person claiming the right to the debtor's payment has in fact been assigned that right by the creditor and until the is forthcoming the debtor may continue to pay the creditor. In a very real sense a contract becomes property at this point where the person to person rights created by two parties become transformed into a transferable asset which can be used to secure loans or can be sold outright (Miller, 1999). Therefore, the third party beneficiary assignment delineated to the banker through a joint trust fund account is more feasible in construction.

The problem of 'non payment of sub contractors' can be efficiently addressed by the mechanism of joint trust fund account. On one hand, the bank will be able to retain its dues and on the other hand, the banker and the owner will be able to closely monitor the transactions between the contractor and subcontractor through the trust fund account. Further technique is to issue joint checks to both the prime and sub contractors or suppliers. Owners have also gone ahead and mandated contractors to establish separate trust bank accounts for receipt and disbursement (Sweet, 1992). In addition, the courts allowing laborers and suppliers to recover as beneficiaries of payment bonds, irrespective of the owner being private or government has overwhelmingly upheld the logic and sanctity of payment bonds (Farnsworth, 1999). However, this model would require the contractor to furnish a payment bond at his/her own cost to indemnify the bank that lends money in the event that the owner did not require it from the contractor.

Given the nature of the financial transactions involved in the model, insurance of risks involved therein gains importance. Environmental issues and poor productivity can result in huge cost implications. Design and estimation errors are covered by the 'Professional Liability Insurance', while environmental risk and cost overrun risks are insured by 'Cost Cap' and 'Cost Overrun Insurance' respectively.

The obligations of the parties involved in the new arrangement are provided below.
Expected Owner's obligation in the new arrangement

- The owner agrees to pay all bills raised by the contractor into a trust fund account as per agreed 'schedule of payments'.

- The owner mandates lien waivers at each billing stage for all material supplied by the contractor and financed by the bank, for which the owner has made payment.

- The owner recognizes the banker as the "Third party beneficiary" for all of the contractor's invoices.

- The contractual agreement with the contractor is based on the AIA format.

\section{Expected Banker's obligation in the new arrangement}

- The banker agrees to fund all the cash requirement of the project as per estimates, until the owner reimburses the same via progress payments into the trust fund account.

- The banker agrees to jointly operate the trust fund account for the disbursement of funds to the sub contractors.

- Banker is assigned as the "Third party beneficiary" for the invoices of the contractor.

\section{Expected Contractor's obligation in the new arrangement}

- The contractor should receive payment from the owner through the trust fund account

- The contractor agrees with the Banker and the Owner to jointly operate the trust fund account with the Banker for the disbursement of funds to sub contractors.

- The contractor agrees to purchase cost overrun insurance and payment bonds and in this regard agrees to indemnify the banker for all loses arising out of reasons attributable to the contractor. 


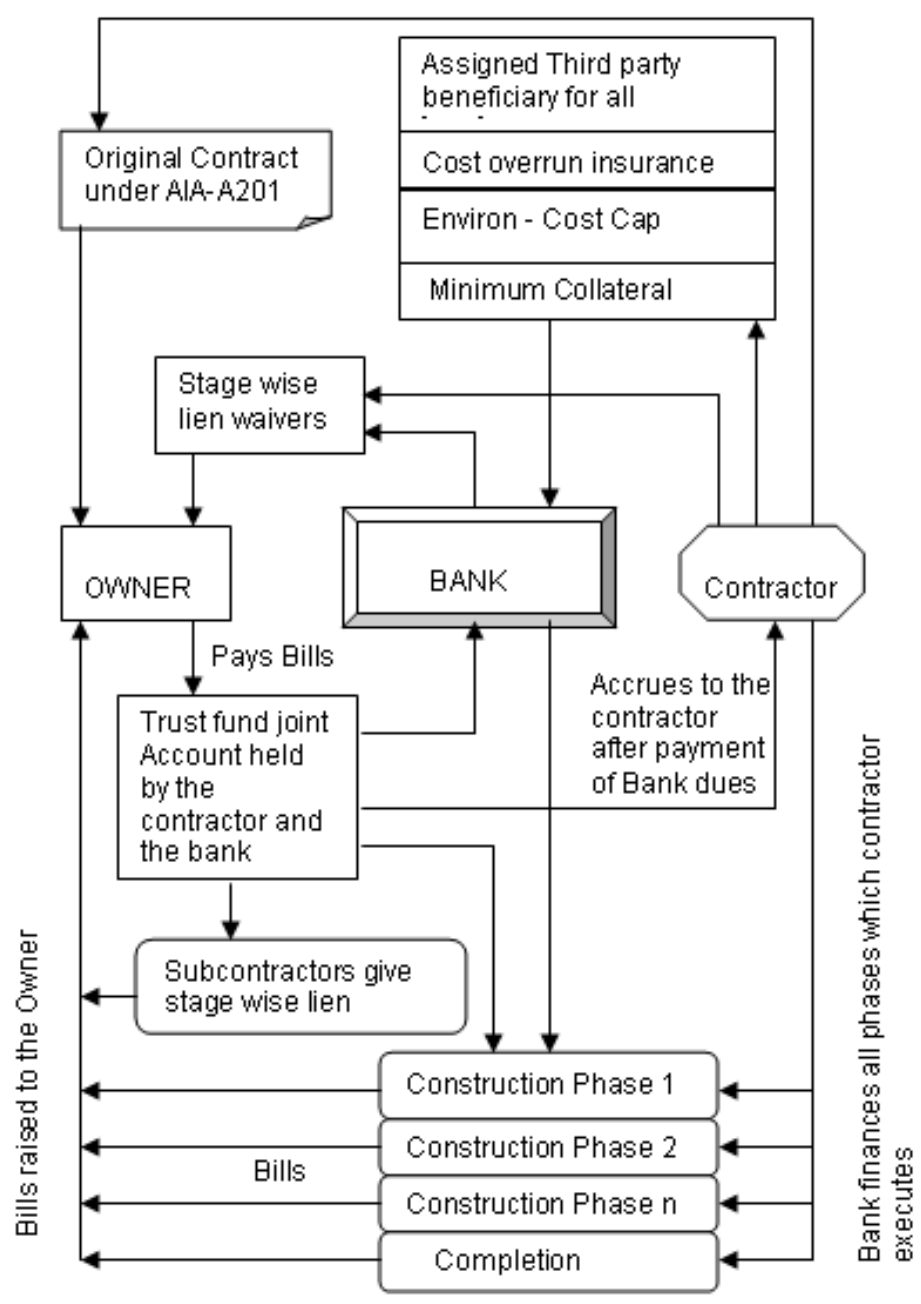

Figure 2: The New Project Finance Model

- The contractor agrees not to extract the free cash flow from the project until the end of the project and the payment of all bank dues.

- The contractor assigns the Banker as the "Third party beneficiary".

- Contractor offers minimum collateral to the bank, which could offset any residual risk that the bank might perceive.

- The AIA format is adopted for the contractual agreement with the owner.
THE POTENTIAL RESPONSE OF THE NEW PROJECT FINANCE ARRANGEMENT TO THE CURRENT PROBLEMS

It is critical to ascertain whether this new arrangement will help alleviating various problems faced by the contractors as highlighted in the foregoing sections. The possible response of the new arrangement to the traditional financing problems are highlighted below:

The liquidity problem: The above arrangement requires a high proficiency in cash flow analysis, 
management and structuring of the progress measurement system and job planning in such a way that the banks and owners are both comfortable with.

The working capital problem: The situation that 'lack of funds inhibiting new project opportunities' can be prevented by carefully structuring the new projects to be funded by project based finance.

Liability of newness, smallness \& adolescence: High growth is required to overcome these liabilities. However it is not possible for a bank to assess risks on a contracting company without having its historical data. This implies that contracting companies, which are new, would atleast have to overcome their start-up liabilities, which is approximately four years after starting up of the firm in order to attract any project based financing from the banks. This difficulty is attributable only to the 'newness' and 'adolescence' of construction companies. 'Smallness' of the company is still unaffected provided the company has historical data to convince the bank. Further investigation is required to encapsulate the liabilities of newness and adolescence in project financing.

Pace of growth: Growth, which is based predominantly on volumes in the construction industry can be hastened to a considerable extent by the ability to take up large sized projects with relatively low initial investment by the contractors. This comes about due to the bank's funding of the initial start up costs of the contractor.

Unplanned growth: Availability of project based financing as shown in Figure 2 can completely offset this problem, provided that the contracting company in question is qualified with a bank and has an understanding with them of the procedural requirements of project based financing.

Thus, out of the major problems, the project based financing method outlined in Figure 2 has the potential to solve at least four of them, including the working capital problem, pace of growth, unplanned growth, and newness.

\section{ASSESSING CONTRACTOR CAPABILITY IN THE PROJECT FINANCE MODEL}

While project finance approach may be a potential panacea to some of the problems of a contractor, a banker would rarely exhibit enthusiasm in lending for such ventures without a thorough analysis of a contractor's competence and some collateral to address the residual risk which the bank might face. Research carried out by Price and Shawa (1997) in the United Arab Emirates where similar financing methods are in practice also supports the above view. A number of attributes of the contracting firm thus gain importance, as they would face possible scrutiny by the lending bank. Some of the attributes as suggested by Strischek, (1996) for the bankers to scrutinize prospective contractors can be adopted. They include: contractors' technical capability to do the job and past experience in doing similar jobs or project; contractors' balance sheet; adequacy of working capital; financial standing of the contractor's owner; project feasibility; tender make up to ensure that the price quoted by the contractor is in the same range as others; cash flow of the project; cash flow of the parent company; progress monitoring system. It is hard for the contractor to convince the banker on some of the attributes such as financial standing of the owner and tender make up as they are beyond the control of the contractor. As the model seeks a strong involvement of the owner, it is expected that the owner, in his/her project's interests and benefits, furnishes the required information and evidence to convince the banker. Adequacy of working capital is another barrier for the contractor to convince the banker, which can be overcome by producing evidence for successful cash flow management in previous projects.

\section{ADVANTAGES AND DISADVANTAGES OF USING PROJECT FINANCE MODEL}

Advantages to the Contractor:

- Value earned for the contractor's competence in undertaking projects.

- Capability to take on larger projects.

- Higher growth opportunities for the contractor company. 
- Creditors have limited recourse to other company assets.

- Ease of accounting for tax purposes.

- Enhancement of bonding capacity due to low risk in the project finance model.

- Possibility of lower insurance and bonding costs.

Disadvantages to the contractor:

- Extensive risk analysis \& management is to be done for each project.

- Large bank fees and other transaction costs can become a burden.

- Well-qualified personnel are required to support the complications of project finance.

- Diversion of funds from the cash flow of the project for other purposes is not possible.

- The high degree of control that a bank will exercise might conflict with other business commitments or agreements, which the contractor may have.

- Liabilities of the trust fund account.

Advantages to the Banks:

- Scope for fee generating services.

- Security of funds lent.

- Short term lending opportunity, which is less cumbersome and risky.

- The project can be insulated from the contractor's possible bankruptcy due to other projects.

- The proposed model opens up a high-risk 'contractor finance' market.

\section{Disadvantages to the Banks:}

- Project risks have to be shared by the banks.

- Due to the limited recourse nature, banks stand to loose at least the interest earnings on the money they lend to the contractor.
- Due to the specialized nature of this transaction, banks will have to appoint someone who has sufficient experience in dealing with project based finance and also has adequate knowledge of the construction industry.

Advantages to the owners:

- Reduction of risk of non performance by contractor due to preventing diversion of cash flow

- Reduction of "Course of construction risk" due to guaranteed payment of sub contractors and making available stage wise lien waivers.

- High degree of legalities mandates professionalism from contractors.

- High degree of control over contractor.

- Lower risk of cost overrun due to high level of project control.

Disadvantages to the owners:

- Higher legal exposure

\section{CONTRACTUAL IMPLICATIONS OF THE MODEL}

Further, the problem of 'non payment of sub contractors' exists in the AIA clauses (American Institute of Architects). The AIA does not require the contractor to submit evidence of payment to sub contractor or lien waivers, as a condition to receiving progress payments. (AIA-A201-Clause 9.3). Nor does certification under A-201, Clause 9.4.2 represent that the architect has reviewed sub contractor or supplier requisitions or that he has determined to whom the previous payments have been made. Finally, clause 9.6.4. states that the owner or architect has no obligation to see to it that the sub contractors are paid except as required by law (Sweet, 1992). The above loop holes in the AIA documents have been plugged by most owners by using trust fund statutes. Trust 
fund statutes impress funds paid to the contractor with a trust, with severe penalties for breach of trust by the contractor. Owners have also gone ahead and mandated contractors to establish separate trust bank accounts for receipt and disbursement (Sweet, 1992). The Texas "Trapping statute" allows an owner to withhold, and pay sub contractor directly if the latter notifies the owner that it has not been paid and the prime contractor has no objection.

The above two options are not very different from the arrangement suggested in Figure 2, except that the bank is the only major subcontractor and has joint signing authority for the trust fund account. Another technique is to issue joint checks to both, the prime and sub contractors or suppliers (Sweet, 1992). This again prevents diversion of project cash flow. Thus by creating a trust fund account or by issuing joint checks for the payment due to various parties including the bank, the diversion of funds can be prevented.

\section{VALIDATION OF IMPETUS TO GROWTH}

The growth of a construction contracting company under project finance can be assessed using the historical data of that company. However on account of the unavailability of such data to the researcher, the pertinent financial data have been assumed. The profitability of a construction company has been constructed as given in Table 1 , over a period of 13 years wherein the Construction Company, hereinafter called as 'company', has been funded by the line of credit mechanism.

Column 5 is the turnover of business the company can anticipate assuming that any given project will have at least four running account bills leading to project completion. Column 6 indicates a profit of $8 \%$ on the turnover that a small construction company can expect. Note that this is higher than the industry average, which stands at $7 \%$. This has been assumed arbitrarily to account for the low overheads that a small company is likely to have. Column 7 indicates the interest paid by the company for the money borrowed in the line of credit, which is assumed at $20 \%$. Column 8 indicates the amount of earnings that the company can anticipate before taxes and is calculated by deducting the figures in column 7 from those in column 6. Column 9 indicates the taxes that the company will be expected to pay. This has been assumed at a corporate tax rate of $34 \%$. Thus the figures in column 9 are $66 \%$ of those in column 8 . Column 11 indicates the percentage growth in the turnover of the company over the previous year.

On computing the average growth of the turnover (column 11) over a period of 13 years we get an average growth rate of $5.87 \%$ every year. This is the likely average growth for a company using the line of credit mechanism for funding its operation.

On the other hand consider the same company having secured project finance for some or one of its projects. This has been depicted in Table 2 . Note that this table has three additional columns; $5 \mathrm{~A}, 5 \mathrm{~B}$, and $5 \mathrm{C}$. All other columns except column 6 are identical. Column $5 \mathrm{~A}$ indicates the amount of project financing that the company has secured .The sum of $\$ 150,000$ has been arbitrarily assumed. The reason that project finance funds are being sought only in the sixth year of operation is because the liability of adolescence, newness and smallness, begin to recede only after 5 years (refer Figure 1).

Column 5B indicates the turnover that can be achieved using additional project finance funds and the assumption again is that there will be at least four running account bills leading to project completion. The figures in column $5 \mathrm{~B}$ are thus 4 times those in $5 \mathrm{~A}$. Column $5 \mathrm{C}$ is the sum total of column 5B and 5 and indicates the total turnover of the company.

When compared for annual growth in volume (column 11) Tables 1 and 2 indicate that infusion of project finance funds results in an abrupt increase in turn over. Assuming that the company avails project finance funds keeping in view the elements of sustainable growth outlined in the foregoing pages, the average growth for a period of 13 years for this company comes out to be $12.28 \%$ as computed from column 11 of Table 2 . This is twice the average growth computed from column 11 of Table 1. However this growth rate of $12.28 \%$ needs to be adjusted for increased insurance costs arising out of the Project Finance arrangement, which is enunciated below. 


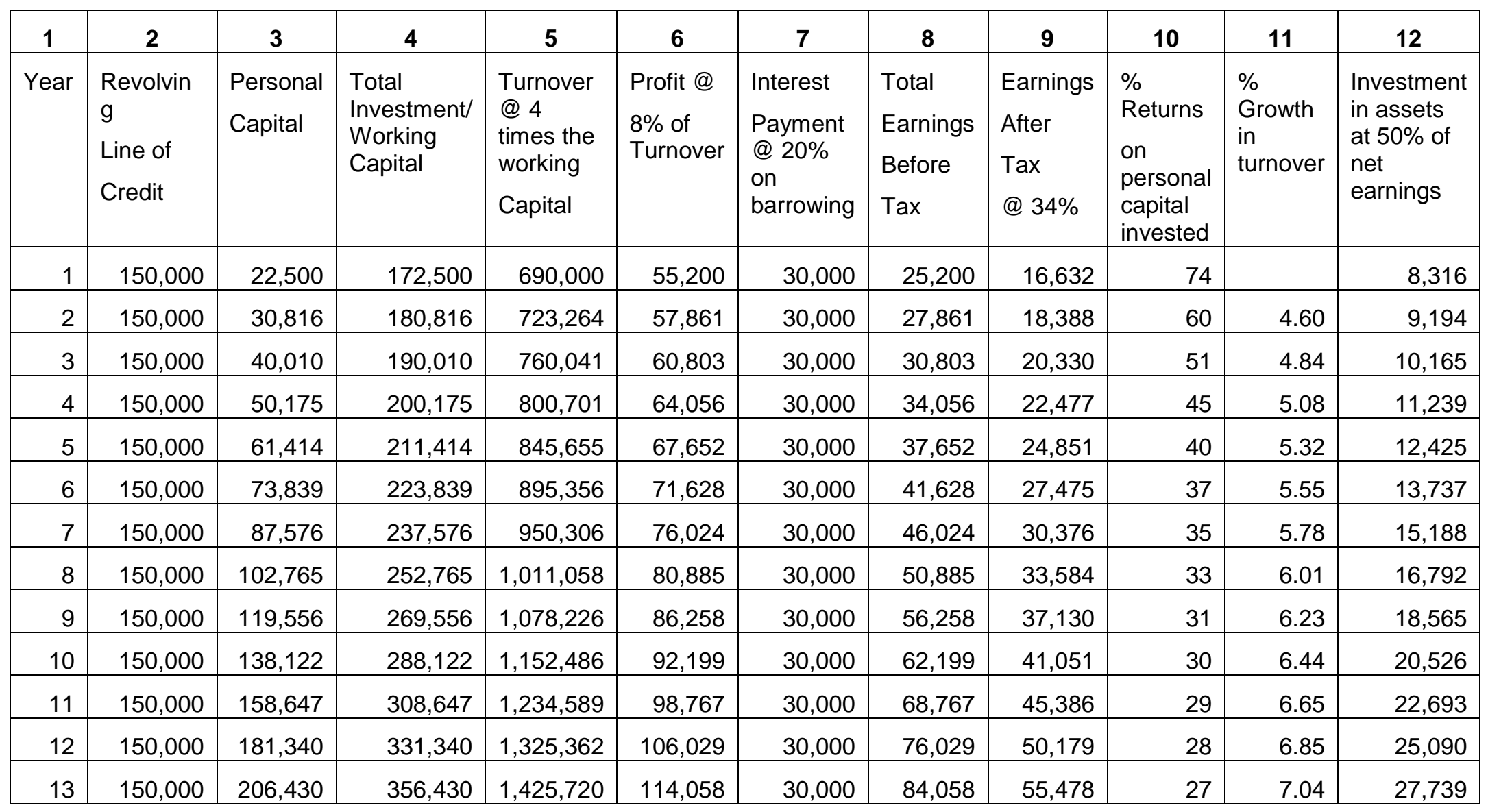

Table 1: Company funded by the Line-of-Credit mechanism 


\begin{tabular}{|c|c|c|c|c|c|c|c|c|c|c|c|c|c|c|}
\hline 1 & 2 & 3 & 4 & 5 & $5 \mathrm{~A}$ & $5 B$ & $5 \mathrm{C}$ & 6 & 7 & 8 & 9 & 10 & 11 & 12 \\
\hline Year & $\begin{array}{l}\text { Revolving } \\
\text { Line of } \\
\text { Credit }\end{array}$ & $\begin{array}{l}\text { Personal } \\
\text { Capital }\end{array}$ & $\begin{array}{l}\text { Total } \\
\text { Investment/ } \\
\text { Working } \\
\text { Capital }\end{array}$ & $\begin{array}{l}\text { Turnover } \\
@ 4 \\
\text { times the } \\
\text { working } \\
\text { Capital }\end{array}$ & $\begin{array}{l}\text { Project } \\
\text { Finance } \\
\text { (PF) } \\
\text { fund }\end{array}$ & $\begin{array}{l}\text { Turnover } \\
\text { using PF } \\
\text { Fund }\end{array}$ & $\begin{array}{l}\text { Total } \\
\text { turnover }\end{array}$ & $\begin{array}{l}\text { Profit @ } \\
8 \% \text { of } \\
\text { Turnover }\end{array}$ & $\begin{array}{l}\text { Interest } \\
\text { Payment } \\
@ 20 \% \\
\text { on } \\
\text { barrowing }\end{array}$ & $\begin{array}{l}\text { Total } \\
\text { Earnings } \\
\text { Before } \\
\text { Tax }\end{array}$ & $\begin{array}{l}\text { Earnings } \\
\text { After } \\
\text { Tax } \\
\text { @ 34\% }\end{array}$ & $\begin{array}{l}\text { \% } \\
\text { Returns } \\
\text { on } \\
\text { personal } \\
\text { capital } \\
\text { invested }\end{array}$ & $\begin{array}{l}\text { \% } \\
\text { Growth } \\
\text { in } \\
\text { turnover }\end{array}$ & $\begin{array}{l}\text { Investment } \\
\text { in assets } \\
\text { at } 50 \% \text { of } \\
\text { net } \\
\text { earnings }\end{array}$ \\
\hline 1 & 150,000 & 22,500 & 172,500 & 690,000 & 0 & 0 & 690,000 & 55,200 & 30,000 & 25,200 & 16,632 & 74 & & 8,316 \\
\hline 2 & 150,000 & 30,816 & 180,816 & 723,264 & 0 & 0 & 723,264 & 57,861 & 30,000 & 27,861 & 18,388 & 60 & 4.60 & 9,194 \\
\hline 3 & 150,000 & 40,010 & 190,010 & 760,041 & 0 & 0 & 760,041 & 60,803 & 30,000 & 30,803 & 20,330 & 51 & 4.84 & 10,165 \\
\hline 4 & 150,000 & 50,175 & 200,175 & 800,701 & 0 & 0 & 800,701 & 64,056 & 30,000 & 34,056 & 22,477 & 45 & 5.08 & 11,239 \\
\hline 5 & 150,000 & 61,414 & 211,414 & 845,655 & 0 & 0 & 845,655 & 67,652 & 30,000 & 37,652 & 24,851 & 40 & 5.32 & 12,425 \\
\hline 6 & 150,000 & 73,839 & 223,839 & 895,356 & 150,000 & 600,000 & $1,495,356$ & 119,628 & 60,000 & 59,628 & 39,355 & 53 & 43.45 & 19,677 \\
\hline 7 & 150,000 & 93,516 & 243,516 & 974,066 & 150,000 & 600,000 & $1,574,066$ & 125,925 & 60,000 & 65,925 & 43,511 & 47 & 5.00 & 21,755 \\
\hline 8 & 150,000 & 115,272 & 265,272 & $1,061,087$ & 150,000 & 600,000 & $1,661,087$ & 132,887 & 60,000 & 72,887 & 48,105 & 42 & 5.24 & 24,053 \\
\hline 9 & 150,000 & 139,324 & 289,324 & $1,157,298$ & 250,000 & $1,000,000$ & $2,157,298$ & 172,584 & 80,000 & 92,584 & 61,105 & 44 & 23.00 & 30,553 \\
\hline 10 & 150,000 & 169,877 & 319,877 & $1,279,509$ & 250,000 & $1,000,000$ & $2,279,509$ & 182,361 & 80,000 & 102,361 & 67,558 & 40 & 5.36 & 33,779 \\
\hline 11 & 150,000 & 203,656 & 353,656 & $1,414,625$ & 400,000 & $1,600,000$ & $3,014,625$ & 241,170 & 110,000 & 131,170 & 86,572 & 43 & 24.38 & 43,286 \\
\hline 12 & 150,000 & 246,942 & 396,942 & $1,587,769$ & 400,000 & $1,600,000$ & $3,187,769$ & 255,022 & 110,000 & 145,022 & 95,714 & 39 & 5.43 & 47,857 \\
\hline 13 & 150,000 & 294,799 & 444,799 & $1,779,197$ & 500,000 & $2,000,000$ & $3,779,197$ & 302,336 & 130,000 & 172,336 & 113,742 & 39 & 15.65 & 56,871 \\
\hline
\end{tabular}

Table 2: Company funded by the Project Finance method 


\section{SENSITIVITY ANALYSIS FOR THE IMPACT OF INSURANCE COSTS}

As mentioned earlier in this article, the insurance for cost over run in particular adds up $1 \%$ to $2 \%$ on the project cost. For the purpose of calculating the impact of increased insurance costs on growth we will consider the increased cost to be at $1 \%$ and thus reduce the profit margin of the contractor by $1 \%$. The corresponding calculations are reflected in Table 3 and it is seen that the profitability of the contractor drops to $7 \%$ of the turnover and the average growth over a period of 13 years drops to $11.42 \%$ from $12.28 \%$ achieved in Table 2 . Thus we see that even if we assume that Project finance attracts higher insurance costs the growth rate achievable with this method is greater than that can be achieved in a traditional "Line of credit" arrangement.

A comparison of the growth rates generated by both methods of financing is graphically shown in Figure 3. While the PF model is highly non-linear in comparison with the LOC model, the average linear growth rate over a period of 13 years works up to be $11.42 \%$. Consequently, the contractor can anticipate doing a turnover of USD 3,411,966/- in the $13^{\text {th }}$ year of profitable operation, which is $239 \%$ higher than that he could anticipate using the LOC model.

\section{EXPERT OPINION ON THE MODEL}

The feasibility of the proposed project-financing model was examined by seeking opinions from three major parties (Bankers, Owners and Contractors). The connectivity between the various elements and the responsibility arising out of the same as contractual obligations, were structured as questions in separate questionnaires designed for each of the potential parties to the mechanism. There were 13 different samples including 5 bankers, 5 owners and 3 contractors. The responses to each of the questions were solicited through personal interviews lasting over two hours and their voice was recorded with their permission. Due to the lengthy nature of the discussion with the bankers, owners and contractors, the opinions of various parties gathered in those interviews are summarized as follows.
All banks have agreed to lend money on the basis of the proposed model and adopt the required contractual obligations. While some bankers perceived lower risk in the model others sought more legal opinion. The assumption of a $20 \%$ interest rate on a consolidated basis in the calculations in Tables 1,2 and 3 stands validated by their answers that the consolidated interest including the banks management fees is not likely to exceed $10 \%$. This in turn serves to strengthen achievable growth and profitability calculated in Tables 1 and 2. The assumption that "project based finance is feasible only after a four year period" is also validated by the bankers responding this period to be within a range of 3 to 10 years.

The discussion with the owners, in general, showed a positive response to the model. In specific, they strongly argued that the insurance and payment bond costs would be much lower than the existing arrangements. This serves to augment the envisaged growth rates and also makes the model friendlier to the insurance companies. The discussion with the owners brought to light the limitations that may be posed by the model. One of the owners who represented the government expressed inability to pay into the trust fund account and hence deemed the model not serving their interests.

It became evident in the discussion with the contractors that, they would be agreeable to their contractual obligations under the proposed model. One of the contractors being very small in size and new in the industry expressed an inability to dispense with using the free cash flow generated from the project or to purchase bonds.

\section{MODEL ASSESSMENT BY "WHAT IF - ANALYSIS"}

In this section, the model is hypothetically assessed within the context of engineering, legal and financial scenarios using "What if? Analysis". The analysis is based on the foregoing discussions of the model and the views and subjective analysis of the author. The analysis is presented in Table 4. 


\begin{tabular}{|c|c|c|c|c|c|c|c|c|c|c|c|c|c|c|}
\hline 1 & 2 & 3 & 4 & 5 & $5 \mathrm{~A}$ & $5 B$ & $5 C$ & 6 & 7 & 8 & 9 & 10 & 11 & 12 \\
\hline Year & $\begin{array}{l}\text { Revolving } \\
\text { Line of } \\
\text { Credit }\end{array}$ & $\begin{array}{l}\text { Personal } \\
\text { Capital }\end{array}$ & $\begin{array}{l}\text { Total } \\
\text { Investment/ } \\
\text { Working } \\
\text { Capital }\end{array}$ & $\begin{array}{l}\text { Turnover } \\
@ 4 \\
\text { times the } \\
\text { working } \\
\text { Capital }\end{array}$ & $\begin{array}{l}\text { Project } \\
\text { Finance } \\
\text { (PF) } \\
\text { fund }\end{array}$ & $\begin{array}{l}\text { Turnover } \\
\text { using PF } \\
\text { Fund }\end{array}$ & $\begin{array}{l}\text { Total } \\
\text { turnover }\end{array}$ & $\begin{array}{l}\text { Profit @ } \\
7 \% \text { of } \\
\text { Turnover }\end{array}$ & $\begin{array}{l}\text { Interest } \\
\text { Payment } \\
@ 20 \% \\
\text { on } \\
\text { barrowing }\end{array}$ & $\begin{array}{l}\text { Total } \\
\text { Earnings } \\
\text { Before } \\
\text { Tax }\end{array}$ & $\begin{array}{l}\text { Earnings } \\
\text { After } \\
\text { Tax } \\
\text { @ 34\% }\end{array}$ & $\begin{array}{l}\% \\
\text { Returns } \\
\text { on } \\
\text { personal } \\
\text { capital } \\
\text { invested }\end{array}$ & $\begin{array}{l}\text { \% } \\
\text { Growth } \\
\text { in } \\
\text { turnover }\end{array}$ & $\begin{array}{l}\text { Investment } \\
\text { in assets } \\
\text { at } 50 \% \text { of } \\
\text { net } \\
\text { earnings }\end{array}$ \\
\hline 1 & 150,000 & 22,500 & 172,500 & 690,000 & 0 & 0 & 690,000 & 48,300 & 30,000 & 18,300 & 12,078 & 54 & & 6,039 \\
\hline 2 & 150,000 & 28,539 & 178,539 & 714,156 & 0 & 0 & 714,156 & 49,991 & 30,000 & 19,991 & 13,194 & 46 & 3.38 & 6,597 \\
\hline 3 & 150,000 & 35,136 & 185,136 & 740,544 & 0 & 0 & 740,544 & 51,838 & 30,000 & 21,838 & 14,413 & 41 & 3.56 & 7,207 \\
\hline 4 & 150,000 & 42,343 & 192,343 & 769,370 & 0 & 0 & 769,370 & 53,856 & 30,000 & 23,856 & 15,745 & 37 & 3.75 & 7,872 \\
\hline 5 & 150,000 & 50,215 & 200,215 & 800,860 & 0 & 0 & 800,860 & 56,060 & 30,000 & 26,060 & 17,200 & 34 & 3.93 & 8,600 \\
\hline 6 & 150,000 & 58,815 & 208,815 & 835,260 & 150,000 & 600,000 & $1,435,260$ & 100,468 & 60,000 & 40,468 & 26,709 & 45 & 44.20 & 13,354 \\
\hline 7 & 150,000 & 72,169 & 222,169 & 888,678 & 150,000 & 600,000 & $1,488,678$ & 104,207 & 60,000 & 44,207 & 29,177 & 40 & 3.59 & 14,588 \\
\hline 8 & 150,000 & 86,758 & 236,758 & 947,031 & 150,000 & 600,000 & $1,547,031$ & 108,292 & 60,000 & 48,292 & 31,873 & 37 & 3.77 & 15,936 \\
\hline 9 & 150,000 & 102,694 & 252,694 & $1,010,777$ & 250,000 & $1,000,000$ & $2,010,777$ & 140,754 & 80,000 & 60,754 & 40,098 & 39 & 23.06 & 20,049 \\
\hline 10 & 150,000 & 122,743 & 272,743 & $1,090,973$ & 250,000 & $1,000,000$ & $2,090,973$ & 146,368 & 80,000 & 66,368 & 43,803 & 36 & 3.84 & 21,901 \\
\hline 11 & 150,000 & 144,645 & 294,645 & $1,178,579$ & 400,000 & $1,600,000$ & $2,778,579$ & 194,501 & 110,000 & 84,501 & 55,770 & 39 & 24.75 & 27,885 \\
\hline 12 & 150,000 & 172,530 & 322,530 & $1,290,119$ & 400,000 & $1,600,000$ & $2,890,119$ & 202,308 & 110,000 & 92,308 & 60,924 & 35 & 3.86 & 30,462 \\
\hline 13 & 150,000 & 202,992 & 352,992 & $1,411,966$ & 500,000 & $2,000,000$ & $3,411,966$ & 238,838 & 130,000 & 108,838 & 71,833 & 35 & 15.29 & 35,916 \\
\hline
\end{tabular}

Table 3: Company funded by the Project Finance method with insurance costs reflecting on average growth 


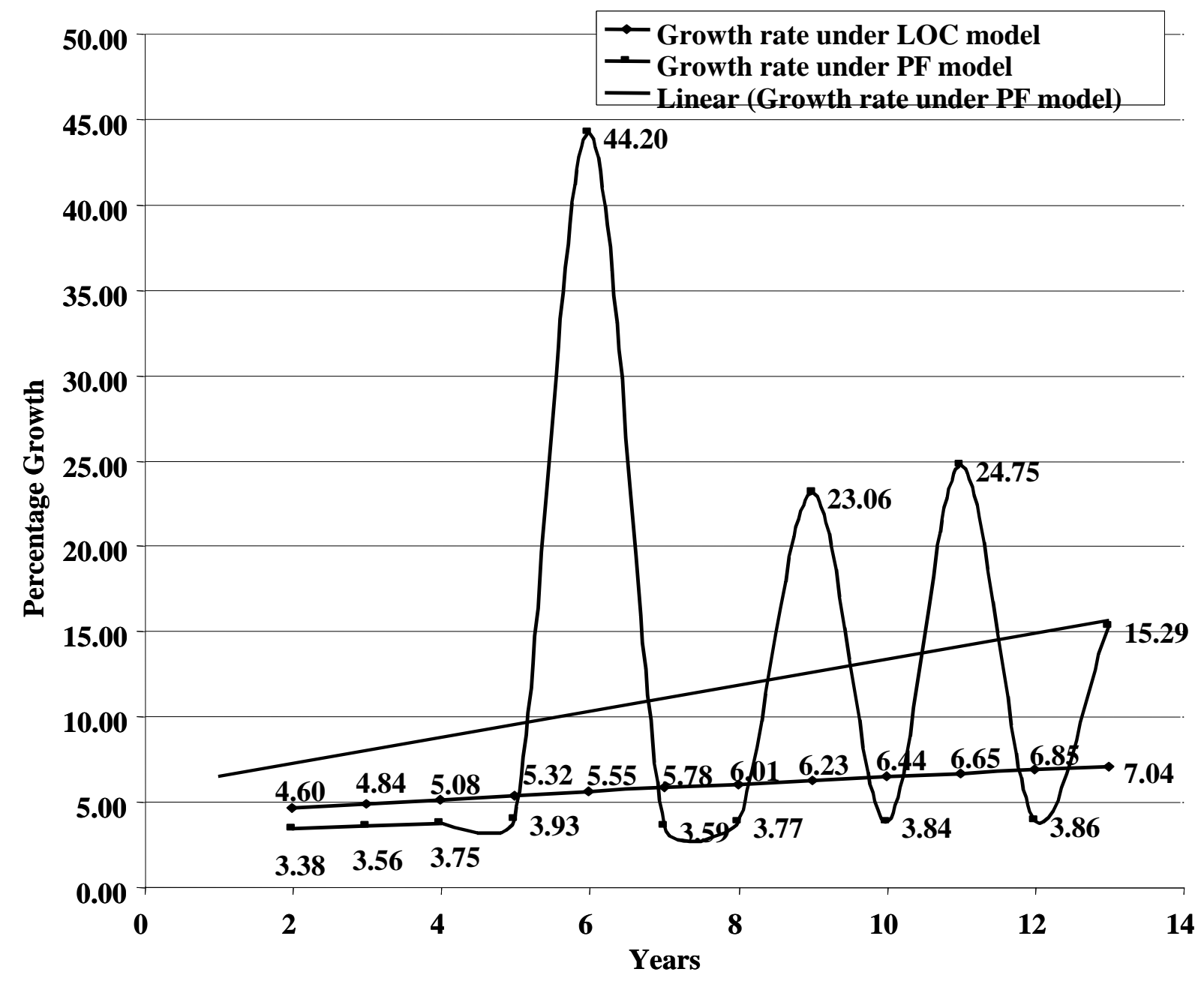

Figure 3: Comparison of the Growth Rates of the PF and the LOC Models. 


\begin{tabular}{|c|c|c|}
\hline & What if? Situations & Responses \\
\hline 1. & $\begin{array}{l}\text { What if the contractor fails to perform the job? Then who } \\
\text { will perform the job and who will pay the bank? }\end{array}$ & $\begin{array}{l}\text { Bonding company will perform the job and pay the } \\
\text { bank }\end{array}$ \\
\hline 2. & What if the owner does not pay? & Amounts to breach of contract; Property is liened \\
\hline 3. & What if the subcontractor does not perform? & Prime contractor is responsible for the scope \\
\hline 4. & $\begin{array}{l}\text { How does the contractor's bank become eligible for holding } \\
\text { the lien on the owner's property? }\end{array}$ & $\begin{array}{l}\text { Bank plays the role of a supplier and is hence } \\
\text { eligible }\end{array}$ \\
\hline 5. & $\begin{array}{l}\text { What if, due to the nature of the project, the progress is } \\
\text { nonlinear and results in an abrupt increase in working } \\
\text { capital requirement, thus rendering the start-up money } \\
\text { arrangement with the bank futile? }\end{array}$ & $\begin{array}{l}\text { The borrowing plan should be in accordance with } \\
\text { progress, whether linear or non-linear. }\end{array}$ \\
\hline 6 & What if the project cost overruns? & $\begin{array}{l}\text { Contractor will bear it personally or through } \\
\text { insurance. }\end{array}$ \\
\hline 7 & $\begin{array}{l}\text { What if the contractor's project incurs a loss for some } \\
\text { reason? How will the bank be indemnified? }\end{array}$ & $\begin{array}{l}\text { Contractor will indemnify personally or through } \\
\text { insurance }\end{array}$ \\
\hline 8 & $\begin{array}{l}\text { What if the owner's architect rejects some material that has } \\
\text { been paid for by the bank, but has not been paid for by the } \\
\text { owner yet? }\end{array}$ & $\begin{array}{l}\text { Defective material will be covered by warranty. } \\
\text { Damage due to accident will be covered by } \\
\text { insurance. }\end{array}$ \\
\hline 9 & $\begin{array}{l}\text { What if the banker is not knowledgeable enough to } \\
\text { understand the construction process in order to oversee } \\
\text { disbursement? }\end{array}$ & Banker can use a title company. \\
\hline 10 & $\begin{array}{l}\text { What if AIA -A-201, A-301, A-311 and A312 are not the } \\
\text { norm? }\end{array}$ & Contractual arrangement will have to be redrafted \\
\hline 11 & $\begin{array}{l}\text { Why should the banker be assigned as a third party } \\
\text { beneficiary to all of the invoices if the payment bonds } \\
\text { already indemnify him? }\end{array}$ & $\begin{array}{l}\text { As the Banker is to receive and control payments } \\
\text { into the trust fund account. }\end{array}$ \\
\hline 12 & $\begin{array}{l}\text { Why should an owner cooperate with a contractor with } \\
\text { such an arrangement if he can find another contractor who } \\
\text { can operate traditionally? }\end{array}$ & Owner has numerous hidden benefits \\
\hline 13 & $\begin{array}{l}\text { Why should the bank and subcontractors give stage wise } \\
\text { lien waivers when A-201 does not mandate it? }\end{array}$ & $\begin{array}{l}\text { Stage wise lien waivers lower risk and } \\
\text { corresponding premiums for the payment bonds. }\end{array}$ \\
\hline 14 & $\begin{array}{l}\text { If a contractor has a track record of having successfully } \\
\text { and profitably executed projects, why should he agree to } \\
\text { retention of his profit in the trust fund account? }\end{array}$ & $\begin{array}{l}\text { Security to banker and incentive for contractor to } \\
\text { finish early. }\end{array}$ \\
\hline 15 & What if there is a labor strike? & $\begin{array}{l}\text { Losses can be recovered under insurance as it is a } \\
\text { 'Force Majeure' event. }\end{array}$ \\
\hline 16 & $\begin{array}{l}\text { The proposed model implies that the contractor will have to } \\
\text { follow "Completed contract method" for accounting. The } \\
\text { government does not easily permit this, hence it may not } \\
\text { be possible to implement the model. }\end{array}$ & $\begin{array}{l}\text { Percentage completion method can be easily } \\
\text { followed. In this case it becomes very accurate; } \\
\text { minimizing the liabilities of tax look back. }\end{array}$ \\
\hline 17 & $\begin{array}{l}\text { What if the contractor has exhausted his bonding capacity } \\
\text { in other projects? }\end{array}$ & $\begin{array}{l}\text { Risk in this model is low, hence bonding company } \\
\text { could consider increase in bonding capacity. }\end{array}$ \\
\hline 18 & $\begin{array}{l}\text { In allowing such tight control by the bank, is there not a risk } \\
\text { of losing ownership of the contractor's company? }\end{array}$ & $\begin{array}{l}\text { Bank may only sell a loan, not an ownership stake in } \\
\text { the contractor's company. }\end{array}$ \\
\hline 19 & $\begin{array}{l}\text { Why should a bank lend without collateral or with minimum } \\
\text { collateral when currently they seek and get collateral for } \\
\text { their lending? }\end{array}$ & $\begin{array}{l}\text { Contractors are a high-risk segment to bankers and } \\
\text { the segment is currently not exploited. }\end{array}$ \\
\hline 20 & $\begin{array}{l}\text { What if the legal costs are so high that the venture } \\
\text { becomes non-viable? }\end{array}$ & $\begin{array}{l}\text { Cost Benefit analysis may have to be done before } \\
\text { abandoning the project. }\end{array}$ \\
\hline 21 & $\begin{array}{l}\text { What if a 'Force Majeure' event occurs on site and the } \\
\text { material or works not paid for by the owner are lost or } \\
\text { destroyed? }\end{array}$ & Stands covered by insurance \\
\hline 22 & $\begin{array}{l}\text { At times the banks may employ 'Title companies'. What if a } \\
\text { Title company hired by the bank makes a mistake or } \\
\text { defrauds and authorizes release of more money from the } \\
\text { trust fund account? }\end{array}$ & $\begin{array}{l}\text { Losses can be recovered from the title company's } \\
\text { insurance provider. }\end{array}$ \\
\hline 23 & $\begin{array}{l}\text { What if the banker and the contractor come in league and } \\
\text { defraud the trust fund account together? }\end{array}$ & The model does not offer immunity to fraud. \\
\hline
\end{tabular}

Table 4: What If? Analysis 


\section{ANTICIPATED LIMITATIONS}

- The model may not work for government contracts, as two of the owners who represented the government expressed inability to pay the contractor's invoices into trust fund accounts.

- The model may not work for subcontractors attempting to use the proposed model to secure finance, as there would be two levels of indemnification involved and possibly three banks. The financial and legal costs of the model may also deem the model nonviable for subcontractors with very small turnover.

- $\quad$ The proposed model requires the bank to employ construction related experts.

\section{CONCLUSIONS}

An alternate Project Finance system has been proposed in this paper. Given the agreement of various parties as outlined from the interviews, though pending legal approval, the proposed model stands validated on key aspects including contractual, transaction, company growth, and financial risks. Finally, the 'What if - Analysis' addresses some potentially vexing scenarios that were haunting construction financing for a long time.

Thus, given the advantages of project-based financing to the banks, contractors, and owners alike, it can be concluded that there is a scope for the application of project-based financing to small and medium construction projects. However, as outlined in this study, project-based financing requires a lot of attention to details and professional handling on the part of both the lender and the borrower, and may be limited in applicability to private contracts. The model yet requires to be validated empirically with real world data for different project circumstances. It also sets a new direction for future research in construction financing.

\section{REFERENCES}

Abudayyeh, O.Y., \& Rasdorf, W.J., 1993.

Prototype integrated cost and schedule control system. Journal of computing in civil engineering, ASCE, 7(2), 181-199.

Aldrich, H.A. and Auster, E., 1986. Even dwarf started small: Liabilities of size \& age and their strategic implications. In: Staw, B. and Cummings, L.L., ed. Research in organizational behavior. Greenwich, JAI Press, Greenwich.

BizStats., 2002. S - Corporations profitability \& expense ratios: manufacturing \& construction industries-US national averages, Available from: www.bizstats.com/scorpmfc1.htm [Accessed 24 September 2002].

Carr, R.I., 1993. Cost schedule and time variances integration. Journal of construction engineering \& management, ASCE, 119(2), 245265

CFMA, 2002. Construction industry annual financial survey. Available from: www.cfma.org [Accessed 28 September 2002]

Cook, A.E., 1991. Construction tendering. London: Batsford.

Westerfield, R. and Jaffe., 1996. Corporate Finance". USA: Irwin Series.

Cushman, R.F. and Bigda, J.P., 1985. Construction Business Handbook: a practical guide to accounting, credit, finance, insurance and law for the construction industry. New York: Mc.Graw Hill.

Donaldson G., 1984. Managing corporation wealth: the operation of a comprehensive financial goal system. New York: Praeger.

Farnsworth, E. A., 1999. Contracts. New York: Aspen.

Higgins, R.C, 1981. Sustainable growth under inflation. Financial management, Autumn.

Finnerty, J.D., 1996. Project Financing. New York: John Wiley \& sons.

Schaufelberger, J., 1991. Risky business: Why so many contractors fail. Seattle daily journal of commerce online edition. Available from: www.djc.com/special/construct99/10050591 (Accessed 20 September 2002).

Kale, S. and Arditi, D., 1998. Business failures: Liabilities of Newness, Adolescence, \& Smallness. 
Journal of construction engineering and management, ASCE, 124(6), 458-464.

Navon, R., 1996. Company level cash flow management. Journal of construction engineering and management, ASCE, 122(1), 22-29.

Price A. D F., and Shawa H., 1997. Survey of Project related finance in UAE. Journal of construction engineering and management, 123(3), 223-232.

Rappaport A., 1986. Creating Shareholder value: The New Standard for business performance. New York: Free Press.

Singh, S. and Lakanathan, G., 1992. Computer based cash flow model. Proceedings of $36^{\text {th }}$ Annual Transaction, American Association of Cost Engineers, Morgantown, W Va, R.5.1-R.5.14.
Strischek, D., 1996. Analyzing construction contracting. Risk Management Association, USA.

Sweet, J., 1992. Sweet on Construction Industry Contracts. New York: John Wiley and sons.

UBS Warburg, UBS., 2002. Available from: www.ubswarburg.com/researchweb [Accessed 28 September 2002].

U.S. Census Bureau., 2002. Minority-owned firms grow four times faster

than national average, Census Bureau reports.

Available from: www.census.gov/Press-

Release/www/2001/cb01-115.html [Accessed 28

September 2002].

Miller, W.W., 1999. Contracts - Problems, Cases, and Materials. USA: Academic Press. 